\title{
Element Composition of the Atmospheric Depositions in Bangladesh
}

\author{
Jatish Chandra Biswas, Md Mozammel Haque*, Mahmuda Akter, A. T. M. Sakhawat Hossain, \\ Faruk Hossain Khan, Md Zakaria Ibne Baki, Abu Bakar Siddique Sarker, Md Rafiqul Islam \\ Bangladesh Rice Research Institute, Gazipur, Bangladesh \\ Email: *mhaquesoil@yahoo.com
}

How to cite this paper: Biswas, J.C., Haque, M.M., Akter, M., Hossain, A.T.M.S., Khan, F.H., Baki, M.Z.I., Sarker, A.B.S. and Islam, M.R. (2018) Element Composition of the Atmospheric Depositions in Bangladesh. Journal of Environmental Protection, 9, 948-956.

https://doi.org/10.4236/jep.2018.99059

Received: June 9, 2018

Accepted: August 12, 2018

Published: August 15, 2018

Copyright $\odot 2018$ by authors and Scientific Research Publishing Inc. This work is licensed under the Creative Commons Attribution International License (CC BY 4.0).

http://creativecommons.org/licenses/by/4.0/

\begin{abstract}
Compositions of dry and wet atmospheric depositions vary depending on geographic locations and industrialization. Fog waters were collected from different regions of Bangladesh along with rain, sub-surface irrigation water and dust particles from Gazipur and compositions were analyzed. The compositions of fog water varied greatly among locations. The ammonium nitrogen $\left(\mathrm{NH}_{4}^{+}-\mathrm{N}\right)$ content was the highest (36 - $\left.37 \mathrm{ppm}\right)$ in Gazipur district and the lowest in Sylhet district (3.2 - 3.6 ppm). Phosphorus (5.2 - $5.5 \mathrm{mg} / \mathrm{L}), \mathrm{K}$ (29.5 - $30 \mathrm{mg} / \mathrm{L}), \mathrm{S}(11.0-11.5 \mathrm{mg} / \mathrm{L}), \mathrm{Zn}(2.9-3.3 \mathrm{mg} / \mathrm{L}), \mathrm{Na}(11.7-12.5$ $\mathrm{mg} / \mathrm{L}), \mathrm{Ca}(22.0-23.3 \mathrm{mg} / \mathrm{L})$ and $\mathrm{Cd}(0.14-0.17 \mathrm{mg} / \mathrm{L})$ contents were also higher in Gazipur district. Dust particles, rain and sub-surface irrigation water of Gazipur district contained considerable amounts of macro and micro elements. We conclude that dry and wet atmospheric depositions varied depending on locations and industrial development. Such study needs to be correlated with ecological consequences and soil fertility management.
\end{abstract}

\section{Keywords}

Water, Dust, Chemical Composition, Regions

\section{Introduction}

Fog as mist or liquid or solid hydrometeor particles or a near-surface cloud in the air [1] contains different suspended or dissolved materials. It is a very complex and dynamic medium allowing both reorganization and removal of particle mass [2]. The sources, formation processes and transport corridors of these particles in moist air [3], their dissolution, evaporation and eventual deposition to the surface determine the chemistry of fog. In addition, the deposition of fog droplets to the underlying surface has an impact on the average chemical com- 
position of liquid water as does the evaporation during the dissipation phase of a fog event [4]. The field of fog research is comparatively young, while first studies on fog water chemistry started in the beginning of the 1900s [5] and have received more attention since 1980s [1]. Fog water and cloud play an important role to the atmospheric chemistry, air quality and atmospheric pollutants due to the intense combustion of fossil fuels and higher industrial emissions in some areas of East Asia [1] [6] [7] [8] [9].

Fog droplets with very high concentrations of particles and acidic gases (e.g., $\mathrm{SO}_{2}$ and $\mathrm{NO}_{2}$ ) are characteristics of polluted fog events in densely populated areas having serious negative effects on human health [10] [11] [12]. Aerosol components, such as sulfates, are air pollutants and can have long term health impacts [10] [11] [13]. Besides, fog water also deposits significant amounts of nutrients into the ecosystem and thus it can play a crucial role in ecosystem maintenance and degradation [14] [15].

Dust from different sources mixed with clean or dirty air and thus can affect climate, global biogeochemical cycles and human health [16]. Dust-laden air masses mixed with urban air pollutants also impair human health in megacities such as Beijing, China [17] [18] [19], Delhi, India [20] and Dhaka, Bangladesh [21]. Build up of dusts in air is increasing because of urbanization and industrial development. It can be deposited with rain water, fog or dry deposition and their chemical compositions vary seasonally. Generally the highest concentrations of dust occur in winter-spring months [16] depending on geographic location. Characterization of wet and dry depositions is important for regulators and researchers because of their potential impact on climate forcing and global warming [22] along with ecosystem management. As industrialization and urbanization are increasing in Bangladesh, we speculate that different materials are depositing in different parts of the country. However, no report is available in this part of the world regarding deposition through wet and dry methods. So, a study was undertaken to determine chemical compositions of dust particles and fog water for different regions of Bangladesh.

\section{Materials and Methods}

\subsection{Sample Location and Collection}

Fog waters were collected in winter seasons of 2015-2016 from Habiganj, Rangpur, Sylhet, Sonagazi, Rajshahi, Gazipur and Comilla regions of Bangladesh. Dust particles, subsurface irrigation water and rain water were collected only from the campus of Bangladesh Rice Research Institute (BRRI), Gazipur during 2017. Dust particles and subsurface irrigation water (deep tubewell) were collected in April, and rain water in August, 2017. Fresh white polythene was placed in the field for collection of fog water. The polythene size was 1-x1-m with three replications. After collection of fog water it was transferred into $50 \mathrm{ml}$ plastic bottles. Similarly, deep tubewell water was also collected. Plastic pot was used for collection of rain water at BRRI farm area. All water samples were fil- 
tered (glass A/E filter) within a day of collection and refrigerated at $4^{\circ} \mathrm{C}$ until analysis. Dust particle were collected from Bangladesh agricultural research institute (BARI) and BRRI farm areas. Dust particles were collected in fresh polythene sheet placed beneath 50 trees at $30 \mathrm{~cm}$ above soil surface through shaking of tree branches. After collection, dust particles were mixed and keep in polythene bags for chemical analyses.

\subsection{Chemical Analysis}

Dust particle was analyzed for total $\mathrm{N}$ (Jeldhal methods) and organic carbon content (Walkley and Black method; [23]. One g dust sample was digested using a strong di-acid solution nitric acid and perchloric acid $\left(\mathrm{HNO}_{3}\right.$ and $\left.\mathrm{HClO}_{4}\right)$ for quantifying total $\mathrm{P}, \mathrm{K}, \mathrm{S}, \mathrm{Zn}, \mathrm{Ca}$ and $\mathrm{Na}$ contents by using atomic absorption spectrophotometer (AAS; Shimadzu Model AA-7200, Shimadzu Corporation, Tokyo, Japan) flame photometer (Sherwood Model 410, UK) and Spectrophotometer (V-630 UV, USA). Fog, rain and subsurface irrigation waters were quantified using inductively coupled plasma-optical emission spectrophotometer (GBC model X-100, Australia, [24]).

\subsection{Statistical Analysis}

Statistical analyses were conducted using SAS software [25]. Fisher's protected least significant difference (LSD) was calculated at the 0.05 probability level for making chemical composition mean comparisons.

\section{Results}

\subsection{Fog Water Composition}

In 2015, fog water $\mathrm{pH}$ of Rajshahi (7.52) and Comilla (7.44) was significantly higher than other districts $(6.62$ - 7.03), while the lowest $\mathrm{pH}$ was found in Habiganj district (Table 1). Similar results were observed in 2016. In both the years, the electrical conductivity $(\mathrm{Ec})$ was the highest in Gazipur $(\sim 1.0)$ and the lowest in Habiganj district ( 0.09). Dissolved organic carbon $(8500-8600 \mathrm{mg} / \mathrm{L})$, $\mathrm{NH}_{4}^{+}-\mathrm{N}$ (37-5-37 mg/L), P (5.26 - $\left.5.46 \mathrm{mg} / \mathrm{L}\right), \mathrm{K}(29.5$ - $30.0 \mathrm{mg} / \mathrm{L}), \mathrm{S}(11.33$ $11.51 \mathrm{mg} / \mathrm{L}), \mathrm{Zn}(2.99-3.30 \mathrm{mg} / \mathrm{L}), \mathrm{Na}(11.65-12.50 \mathrm{mg} / \mathrm{L})$ and $\mathrm{Ca}(22.58-23.25$ $\mathrm{mg} / \mathrm{L}$ ) contents were significantly higher at Gazipur than other studied areas of Bangladesh (Table 2). Manganese (Mn) content was the highest in Comilla (2.02 - $2.06 \mathrm{mg} / \mathrm{L})$ and that of $\mathrm{Fe}$ in Sylhet district $(2.31-2.55 \mathrm{mg} / \mathrm{L})$ compared to other districts. Cadmium contents $(0.12-0.17 \mathrm{mg} / \mathrm{L})$ were similar among studied locations.

\subsection{Dust Particle Composition}

Chemical compositions of dust particles from Gazipur site are shown in Table 3. Among the studied elements, Ca concentration was the highest (16,124 ppm) than other elements. However, Mn concentration was the lowest (575 ppm) compared to other elements. About $0.57 \%$ total $\mathrm{N}$ and $1.2 \%$ organic carbon was 
Table 1. pH and Ec of fog water at different regions of Bangladesh.

\begin{tabular}{ccccccccc}
\hline \multirow{2}{*}{ Year } & \multirow{2}{*}{ Parameters } & \multicolumn{7}{c}{ Location } \\
\cline { 3 - 9 } & & Habiganj & Rangpur & Sylhet & Sonagazi & Rajshahi & Gazipur & Comilla \\
\hline \multirow{2}{*}{2015} & $\mathrm{pH}$ & $6.62 \mathrm{e}$ & $7.03 \mathrm{~d}$ & $7.14 \mathrm{c}$ & $7.25 \mathrm{~b}$ & $7.52 \mathrm{a}$ & $6.98 \mathrm{~d}$ & $7.44 \mathrm{a}$ \\
& $\mathrm{Ec}(\mathrm{dS} / \mathrm{m})$ & $0.09 \mathrm{f}$ & $0.33 \mathrm{c}$ & $0.21 \mathrm{e}$ & $0.25 \mathrm{~d}$ & $0.24 \mathrm{e}$ & $1.01 \mathrm{a}$ & $0.37 \mathrm{~b}$ \\
\multirow{2}{*}{2016} & $\mathrm{pH}$ & $6.66 \mathrm{e}$ & $7.01 \mathrm{~d}$ & $7.10 \mathrm{c}$ & $7.22 \mathrm{~b}$ & $7.48 \mathrm{a}$ & $6.92 \mathrm{~d}$ & $7.39 \mathrm{a}$ \\
& $\mathrm{Ec}(\mathrm{dS} / \mathrm{m})$ & $0.088 \mathrm{f}$ & $0.32 \mathrm{c}$ & $0.20 \mathrm{e}$ & $0.26 \mathrm{~d}$ & $0.23 \mathrm{e}$ & $1.00 \mathrm{a}$ & $0.35 \mathrm{~b}$ \\
\hline
\end{tabular}

Small letter in a column compare means at $5 \%$ level by Turkey's test.

Table 2. Elemental compositions (mg/L) of fog water at different regions of Bangladesh.

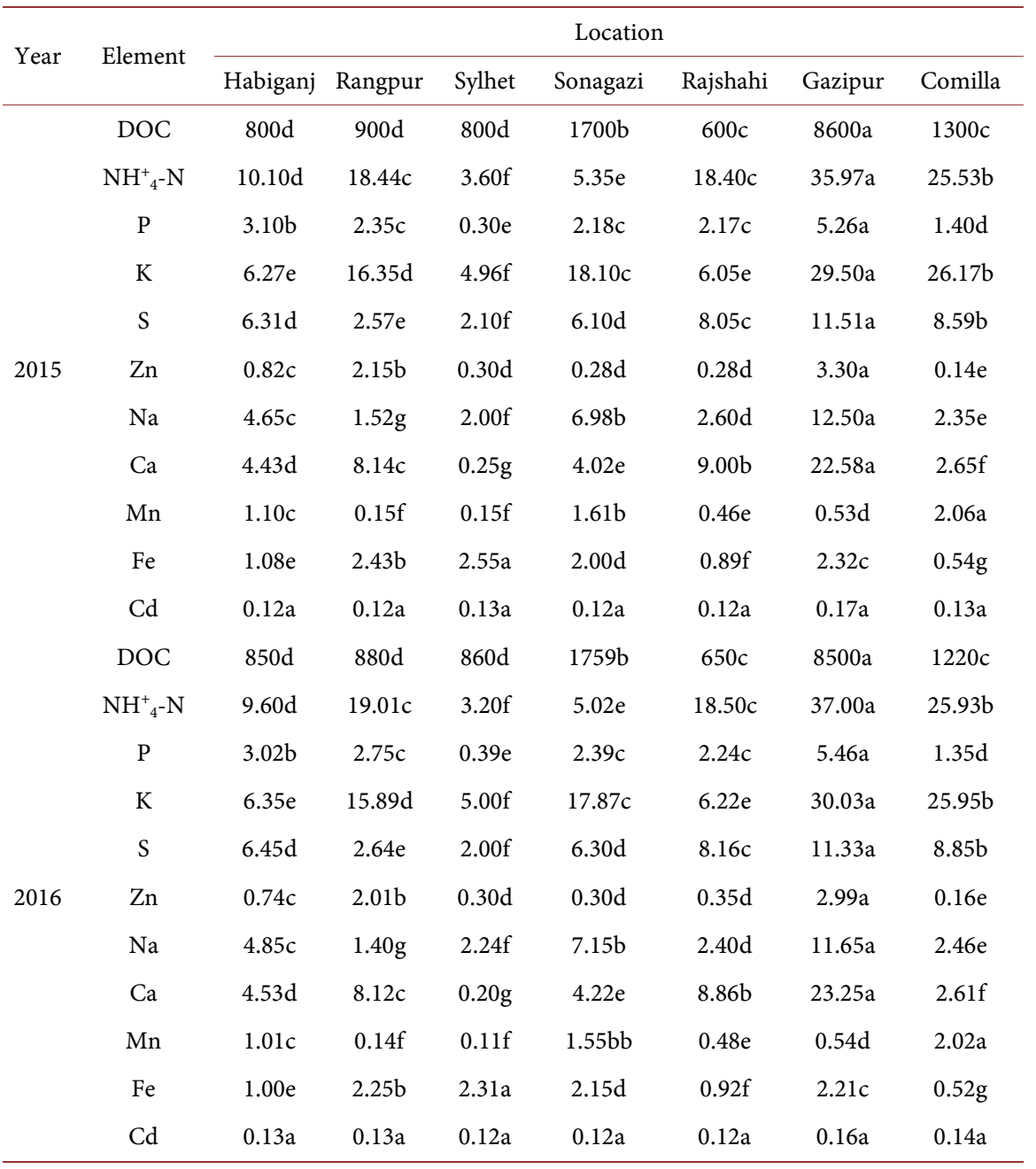

Small letter in a column compare means at $5 \%$ level by Turkey's test.

Table 3. Chemical compositions of dust at Gazipur region of Bangladesh.

\begin{tabular}{|c|c|c|c|c|c|c|c|c|c|}
\hline \multirow{3}{*}{ Parameters } & \multicolumn{9}{|c|}{ Nutrient composition } \\
\hline & \multirow{2}{*}{ OC (\%) } & \multirow{2}{*}{$\mathrm{N}(\%)$} & $\mathrm{P}$ & $\mathrm{K}$ & $S$ & $\mathrm{Zn}$ & $\mathrm{Mn}$ & $\mathrm{Ca}$ & $\mathrm{Na}$ \\
\hline & & & \multicolumn{7}{|c|}{$\mathrm{ppm}$} \\
\hline Dust particle & 1.20 & 0.57 & $1131 \mathrm{e}$ & $4206 c$ & $3528 \mathrm{~d}$ & $5657 \mathrm{~b}$ & $575 \mathrm{f}$ & $16,124 \mathrm{a}$ & $1208 \mathrm{e}$ \\
\hline
\end{tabular}


found in dust particle.

\subsection{Rain and Sub-Surface Irrigation Water Composition}

In Gazipur site, the rain water and sub-surface irrigation water were collected and analyzed. Among studied elements, $\mathrm{K}$ concentration was the highest (41.79 $\mathrm{mg} / \mathrm{L})$ followed by $\mathrm{S}(2.82 \mathrm{mg} / \mathrm{L})$ in rain water compared to other elements (Table 3). In sub-surface water, Sodium concentration was the highest (32.44 $\mathrm{mg} / \mathrm{L})$ followed by $\mathrm{Ca}(2.61 \mathrm{mg} / \mathrm{L})$ and $\mathrm{NH}_{4}^{+}-\mathrm{N}(2.39 \mathrm{mg} / \mathrm{L})$ than other elements. Sub-surface irrigation water contained significantly higher amounts of $\mathrm{Ca}(2.61 \mathrm{mg} / \mathrm{L})$ and $\mathrm{Na}(32.44 \mathrm{mg} / \mathrm{L})$ than rain water. Similarly, $\mathrm{pH}, \mathrm{P}, \mathrm{K}, \mathrm{S}, \mathrm{Ca}$, and $\mathrm{Na}$ values were significant different between rain and sub-surface irrigation water in Gazipur district. Rain water had about two thousand times higher $\mathrm{K}$ concentration than sub-surface irrigation water, while $\mathrm{P}$ and $\mathrm{S}$ also showed about $268 \%$ and $131 \%$ times higher values (Table 4 ).

\section{Discussion}

In Bangladesh, fog is generally observed during later part of November to February. In general, dense fog is observed in December and January, especially North and Southern regions of Bangladesh. Fog is nothing but cloud of condensed water vapor at ground level that forms visible water droplets. It mostly occurs when moist air is cooled below dew point after contact with cold land surface having clear skies at night and gentle breeze ( $<5$ knots). It plays an important role in the earth's ecosystem for the exchange of water and pollutants between atmosphere and biosphere [26]. Our results indicated that a considerable amounts of DOC, $\mathrm{NH}_{4}^{+}-\mathrm{N}, \mathrm{P}, \mathrm{K}, \mathrm{S}, \mathrm{Zn}, \mathrm{Na}$ and $\mathrm{Ca}$ are depositing through fog water (Table 2) and might influence crop production in different regions of Bangladesh [27] [28]. In Gazipur site, fog had higher nutrients load than other regions of Bangladesh (Table 2) might be because of rapid industrialization [29] (Table 5).

In Gazipur, higher amounts of S, $\mathrm{K}$ and $\mathrm{Na}$ were found in rain water (Table 3) of Gazipur site might be because of industrial development including higher number of brick kilns. [21] mentioned that brick kilns are the important sources of $\mathrm{K}, \mathrm{Ca}, \mathrm{Pb}$ and trace elements deposition and thus influences plant response to

Table 4. Chemical compositions of water at Gazipur region of Bangladesh.

\begin{tabular}{|c|c|c|c|c|c|c|c|c|c|c|c|c|}
\hline \multirow{3}{*}{ Parameters } & \multicolumn{12}{|c|}{ Nutrient composition } \\
\hline & \multirow{2}{*}{$\mathrm{pH}$} & \multirow{2}{*}{$\begin{array}{c}\mathrm{Ec} \\
(\mathrm{dS} / \mathrm{m})\end{array}$} & \multirow{2}{*}{$\begin{array}{l}\text { OC } \\
(\%)\end{array}$} & \multirow{2}{*}{$\begin{array}{l}\mathrm{N} \\
(\%)\end{array}$} & $\mathrm{NH}_{4}^{+}-\mathrm{N}$ & $\mathrm{P}$ & $\mathrm{K}$ & $S$ & $\mathrm{Zn}$ & $\mathrm{Mn}$ & $\mathrm{Ca}$ & $\mathrm{Na}$ \\
\hline & & & & & \multicolumn{8}{|c|}{$\mathrm{mg} / \mathrm{L}$} \\
\hline Rain water & $8.10 \mathrm{a}$ & 0.0 & - & - & $2.10 \mathrm{~b}$ & $1.60 \mathrm{a}$ & $41.79 \mathrm{a}$ & $2.82 \mathrm{a}$ & $0.06 \mathrm{a}$ & $0.12 \mathrm{a}$ & $1.43 \mathrm{~b}$ & $2.35 \mathrm{~b}$ \\
\hline $\begin{array}{c}\text { Subsurface } \\
\text { water }\end{array}$ & $7.10 \mathrm{~b}$ & $0.22 \mathrm{a}$ & - & - & $2.39 \mathrm{a}$ & $0.64 \mathrm{~b}$ & $1.81 \mathrm{~b}$ & $2.15 \mathrm{~b}$ & $0.057 \mathrm{a}$ & $0.12 \mathrm{a}$ & $2.61 \mathrm{a}$ & $32.44 \mathrm{a}$ \\
\hline
\end{tabular}

Small letter in a raw compare with rain water and subsurface irrigation water means at $5 \%$ level by Turkey's test. 
Table 5. Industrial set ups in different regions of Bangladesh.

\begin{tabular}{|c|c|c|}
\hline Regions name & CMI 1995-96 & SMI 2005-06 \\
\hline Barisal & 233 & 44 \\
\hline Patuakhali & 109 & 95 \\
\hline Chittagong & 2034 & 2768 \\
\hline Comilla & 1452 & 1095 \\
\hline Noakhali & 556 & 364 \\
\hline Sylhet & 411 & 612 \\
\hline Tangail & 1900 & 3693 \\
\hline Jamalpur & 287 & 295 \\
\hline Mymensingh & 598 & 657 \\
\hline Faridpur & 224 & 60 \\
\hline Dhaka & 10401 & 11392 \\
\hline Khulna & 818 & 1369 \\
\hline Jessore & 375 & 593 \\
\hline Kushtia & 1584 & 707 \\
\hline Bogra & 886 & 1198 \\
\hline Pabna & 8841 & 5158 \\
\hline Rajshahi & 540 & 1864 \\
\hline Dinajpur & 1662 & 589 \\
\hline Rangpur & 672 & 1804 \\
\hline Gazipur & - & $1773^{*}$ \\
\hline
\end{tabular}

Source: SMI 2005-06 and author calculation; Source: CMI 1995-96 and author calculation. ${ }^{\star}$ Source: BBS, 2013.

added nutrients. Our previous findings also showed no added benefit of $S$ and $\mathrm{Zn}$ fertilization in rice crop [30].

Dust emission increases because of agriculture, industry, over grazing, deforestation, construction and military activities [31] [32] and thus impairs human health [31] [33]. Besides, trans-boundary movement of air pollutants also contribute to dry and wet depositions [16] and thus play an important role in manipulating environment. [31] reported that $\mathrm{Ca}$ content increased during twentieth century due to dust emissions from anthropogenic activities in regions vulnerable to desertification. We have also found increased amounts of $\mathrm{Ca}, \mathrm{S}$ and $\mathrm{Zn}$ in the dust, although Gazipur site has no sign of desertification. Besides, vehicle movements has also been increased in Gazipur site since 1990s and thus emission and deposition of $\mathrm{SO}_{\mathrm{x}}$ through dust has been elevated dramatically [34] [35].

\section{Conclusion}

Industrial development and vehicle movements have increased tremendously in 
Gazipur district, Bangladesh and thus the highest amounts of different elements were present in fog water, rain water and dust particles. The consequences of such depositions on ecology and crop performances need to be evaluated.

\section{Acknowledgements}

We greatly acknowledge the help of concerned BRRI regional stations personnel in collecting samples.

\section{Conflicts of Interest}

The authors declare no conflicts of interest regarding the publication of this paper.

\section{References}

[1] Yang, J.Y., Xie, C.E., Shi, C.E., Liu, D.Y., Niu, S.J. and Li, Z.H. (2011) Ion Composition of Fog Water and Its Relation to Air Pollutants during Winter Fog Events in Nanjing, China. Pure and Applied Geophysics, 169, 1037-1052. https://doi.org/10.1007/s00024-011-0342-y

[2] Li, P., Li, X., Yang, C., Wang, X., Chen, J. and Collett Jr., J.L. (2011) Fog Water Chemistry in Shanghai. Atmospheric Environment, 45, 4034-4041.

https://doi.org/10.1016/j.atmosenv.2011.04.036

[3] Seinfeld, J.H. and Pandis, S.N. (2006) Atmospheric Chemistry and Physics. From Air Pollution to Climate Change. 2nd Edition, John Wiley \& Sons, New Jersey.

[4] Degefie, D.T., El-Madany, T.S., Held, M., Hejkal, J., Hammer, E., Dupont, J.C., Haeffelin, M., Fleischer, E. and Klemm, O. (2015) Fog Chemical Composition and Its Feedback to Fog Water Fluxes, Water Vapor Fluxes and Microphysics in the Evolution of Two Events near Paris. Atmospheric Research, 164, 328-338. https://doi.org/10.1016/j.atmosres.2015.05.002

[5] Herckes, P., Marcotte, A., Wang, Y. and Collett, J.L. (2015) Fog Composition in the Central Valley of California over Three Decades. Atmospheric Research, 151, 20-30. https://doi.org/10.1016/j.atmosres.2014.01.025

[6] Raja, S., Ravikrishna, R., Kommalapati, R.R. and Valsaraj, K.T. (2005) Monitoring of Fog Water Chemistry in the Gulf Coast Urban Industrial Corridor: Baton Rouge (Louisiana). Environmental Monitoring and Assessment, 110, 99-120. https://doi.org/10.1007/s10661-005-6281-2

[7] Collett, J.L., Hoag, K.J. and Rao, X. (1999) Internal Acid Buffering in San Joaquin Valley Fog Drops and Its Influence on Aerosol Processing. Atmospheric Environment, 33, 4833-4847. https://doi.org/10.1016/S1352-2310(99)00221-6

[8] Hoag, K.J., Collett, J.L. and Pandis, S.N. (1999) The Influence of Drop Size-Dependent Fog Chemistry on Aerosol Processing by San Joaquin Valley Fogs. Atmospheric Environment, 33, 4817-4832. https://doi.org/10.1016/S1352-2310(99)00268-X

[9] Del Monte, M. and Rossi, P. (1997) Fog and Gypsum Crystals on Building Materials. Atmospheric Environment, 31, 1637-1646. https://doi.org/10.1016/S1352-2310(96)00343-3

[10] Nemery, B., Hoet, P.H.M. and Nemmar, A. (2001) The Meuse Valley Fog of 1930: An Air Pollution Disaster. Lancet, 357, 704-708. https://doi.org/10.1016/S0140-6736(00)04135-0 
[11] Wyzga, R.E. and Folinsbee, L.J. (1995) Health Effects of Acid Aerosols. Water, Air, and Soil Pollution, 85, 177-188. https://doi.org/10.1007/BF00483699

[12] Seinfeld, J.H. (1986) Atmospheric Chemistry and Physics of Air Pollution. Wiley, New York.

[13] Shao, L.Y., Shi, Z., Jones, T.P., Li, J., Whittaker, A.G. and BeruBe, K.A. (2006) Bioreactivity of Particulate Matter in Beijing Air: Results from Plasmid DNA Assay. Science of the Total Environment, 367, 261-272. https://doi.org/10.1016/j.scitotenv.2005.10.009

[14] Weathers, K.C., Likens, G.E., Bormann, F.H., Eaton, J.S., Bowden, W.B. and Andersen, J.L., et al. (1986) A Regional Acidic Cloud/Fog Water Event in the Eastern United States. Nature, 319, 657-658. https://doi.org/10.1038/319657a0

[15] Lakhani, A., Parmar, R.S., Satsangi, G.S. and Prakash, S. (2007) Chemistry of Fogs at Agra, India: Influence of Soil Particulates and Atmospheric Gases. Environmental Monitoring and Assessment, 133, 435-445. https://doi.org/10.1007/s10661-006-9598-6

[16] Kaspari, S., Mayewski, P.A., Handley, M., Kang, S., Hou, S., Sneed, S., Maasch, K. and Qin, D. (2009) A High-Resolution Record of Atmospheric Dust Composition and Variability since A.D. 1650 from a Mount Everest Ice Core. Journal of Climate, 22, 3910-3925. https://doi.org/10.1175/2009JCLI2518.1

[17] Song, Y., Tang, X.Y., Xie, S.D., Zhang, Y.H., Wei, Y.J., Zhang, M.S., et al. (2007) Source Apportionment of PM2.5 in Beijing in 2004. Journal of Hazardous Materials, 146, 24-130. https://doi.org/10.1016/j.jhazmat.2006.11.058

[18] Lu, S.L., Shao, L.Y., Wu, M.H., Jiao, Z. and Chen, X.H. (2007) Chemical Elements and Their Source Apportionment of PM10 in Beijing Urban Atmosphere. Environmental Monitoring and Assessment, 133, 79-85. https://doi.org/10.1007/s10661-006-9561-6

[19] Shao, L.Y., Li, W.J., Xiao, Z.H. and Sun, Z.Q. (2008) The Mineralogy and Possible Sources of Spring Dust Particles over Beijing. Advances in Atmospheric Sciences, 25, 395-403. https://doi.org/10.1007/s00376-008-0395-8

[20] DPCC (Delhi Pollution Control Committee) (2017) Real Time Ambient Air Quality Data. http://www.dpcc.delhigovt.nic.ind

[21] Begum, B.A., Hopke, P.K. and Markwitz, A. (2013) Air Pollution by Fine Particulate Matter in Bangladesh. Air Pollution Research, 4, 75-86. https://doi.org/10.5094/APR.2013.008

[22] IPCC (Intergovernmental Panel on Climate Change) (2007). http://www.ipcc.ch/ipccreports/tar/wg1/016.htm

[23] Allison, L.E. (1965) Organic Carbon. In: Black, C.A., Ed., Methods of Soil Analysis, Agronomy Series No. 9, ASA, Madison, 1367-1376.

[24] Lee, C.H., Park, C.Y., Park, K.D., Jeon, W.T. and Kim, P.J. (2004) Long-Term Effects of Fertilization on the Forms and Availability of Soil Phosphorus in Rice Paddy. Chemosphere, 56, 299-304. https://doi.org/10.1016/j.chemosphere.2004.02.027

[25] SAS Institute (1995) System for Windows Release 6.11. SAS Institute, Cary.

[26] Singh, S., Singh, D. and Rao, V.U.M. (2007) Fog and Dew Analysis at Hisar, India. Journal of Agrometeorology, 9, 118-121.

[27] Biswas, J.C., Haque, M.M. and Saha, P.K. (2017) Rice Yield Potential under Unfavorable Soil Ecosystems in Bangladesh. Asian Journal of Soil Science and Plant Nutrition, 1, 1-10.

[28] Syeda, J.A. and Nasser, M. (2012) Farmers' Perception Regarding Climate Change 
and Crop Production, Especially for Wheat in Dinajpur District. Journal of Environmental Science Natural Resources, 5, 129-136.

[29] Bangladesh Bureau of Statistics (BBS) (2013) Statistics and Informatics Division (SID) Ministry of Planning Government of the People's Republic of Bangladesh (District Statistics, 2011). 37-44.

[30] Haque, M.M., Saleque, M.A., Shah, A.L., Biswas, J.C. and Kim, P.J. (2015) LongTerm Effects of Sulfur and Zinc Fertilization on Rice Productivity and Nutrient Efficiency in Double Rice Cropping Paddy in Bangladesh. Communication in Soil Science and Plant Analysis, 46, 2877-2887. https://doi.org/10.1080/00103624.2015.1104333

[31] Tegen, I., Werner, M., Harrison, S.P. and Kohfeld, K.E. (2004) Relative Importance of Climate and Land Use in Determining Present and Future Global Soil Dust Emission. Geophysical Research Letters, 31, L05105.

https://doi.org/10.1029/2003GL019216

[32] Mahowald, N., Rivera, G. and Luo, C. (200) Comment on "Relative Importance of Climate and Land Use in Determining Present and Future Global Soil Dust Emission". Geophysical Research Letters, 31, L24105.

[33] Prospero, J., Ginoux, P., Torres, O., Nicholson, S. and Gill, T. (2002) Environmental Characterization of Global Sources of Atmospheric Soil Dust Derived from the NIMBUS-7 TOMS Absorbing Aerosol Product. Reviews of Geophysics, 40, Article No. 1002. https://doi.org/10.1029/2000RG000095

[34] Rashid, M.A. (2006) Rise of Readymade Garments Industry in Bangladesh: Entrepreneurial Ingenuity or Public Policy. Workshop on Governance and Development, Dhaka, 11-12 November 2006.

[35] Wahiduddin, M. (2003) Bangladesh: Development Outcomes and Challenges in the Context of Globalization. Conference on the Future of Globalization: Explorations in Light of Recent Turbulence, New Haven, 10-11 October 2003. 